\title{
Influence of dental erosion on the shear bond strength of orthodontic brackets: an in vitro study
}

\author{
Influência da erosão dentária sobre a resistência adesiva ao cisalhamento \\ de bráquetes ortodônticos: um estudo in vitro
}

Felipe Degrazia*

Fabiana Justino**

Renésio Grehs ${ }^{* * *}$

Murilo Rosa ${ }^{* * * *}$

\begin{abstract}
Objective: evaluate the shear bond strength of metallic brackets bonded with two adhesive systems to eroded enamel surfaces. Methods: sixty bovine incisors were used and divided into four groups $(n=15)$. The bonding procedures were performed with metallic brackets and $37 \%$ phosphoric acid etching, and divided as follows: Group 1, healthy enamel with Transbond XT adhesive system (3M Unitek, Monrovia, USA); Group 2, eroded enamel with Transbond XT adhesive system; Group 3, healthy enamel with Orthoprimer/Orthobond adhesive system (Dental Morelli Ltda, Sorocaba, Brazil); and Group 4, eroded enamel with Orthoprimer/Orthobond adhesive system. Teeth erosion was performed with Classic Coke ${ }^{T M}$ during 14 days. After $24 \mathrm{~h}$ of bonding procedures, specimens were subjected to shear loading using a universal machine for mechanical testing at a crosshead speed of $1 \mathrm{~mm} / \mathrm{min}$. Results: the shear bond strength means were: Group 1, 19.04(3.24) MPa; Group 2, 18.6(4.25) MPa; Group 3, 12.76(2.78) MPa; and Group 4, 13.01(3.22) MPa. No statistically significant differences were found between groups 1 and 2, and between groups 3 and 4. Statistically significant differences were found between groups 1 and 3, and between groups 2 and 4 . The adhesive remnant index (ARI) scores indicated no significant differences among the tested groups. Conclusions: acid erosion did not change shear bond strength of metallic brackets bonded with both adhesive systems. Transbond XT adhesive system showed higher shear bond strength than Orthoprimer/Orthobond adhesive system.
\end{abstract}

Keywords: Tooth erosion. Orthodontic brackets. Orthodontic adhesives.

\section{Introduction}

The direct bonding procedures of orthodontic brackets to enamel surfaces revolutionized the orthodontic corrective treatment. Mitchell ${ }^{1}$ (1967) was the first author to relate the use of metallic brackets with retentive bases. In this technique, the bracket adhesion to dental enamel is based on an exchange reaction. The adhesive infiltrates monomer links to the enamel surface by resin tag formation, creating a bonded system. To avoid premature debonding, minimum clinical adhesive strength of ${ }^{6-8} \mathrm{MPa}$ is required, as advised by previous studies ${ }^{2,3}$. Thus, during the clinical bonding procedure, different factors could affect the bonding strength between bracket and enamel, such as different methods of etching ${ }^{4}$, adhesive polymerization time $^{5}$, contamination $^{6}$, adhesive systems ${ }^{7-9}$, and bracket base configuration ${ }^{10}$.

Dental erosion results from the direct demineralization of the enamel surface by exposure to erosive agent of the diet, especially through large ingestion of acidic foods and beverages without the participation of microorganisms ${ }^{11}$. This demineralization is extremely dynamic, and is under the influence of intrinsic (vomiting, regurgitation, chronic heartburn, gastritis, hiatal hernia) and extrinsic factors (excessive consumption of acids) that cause loss of tooth structure. Still, with physical and chemical

http://dx.doi.org/10.5335/rfo.v18i1.3120

MSc in Orthodontic Science by the Federal University of Santa Maria, Santa Maria, RS, Brazil.

Specialist in Orthodontics by UniABO/SC, Florianópolis, SC, Brazil.

*** Dr. in Orthodontics by the Paulista State University/Araraquara, Associate Professor of the Federal University of Santa Maria, Department de Stomatology, Santa Maria, RS, Brazil.

**** MSc in Orthodontics by the Federal University of Rio de Janeiro, Professor of the specialization course at UniABO/SC, Florianópolis, SC, Brazil 
alterations of the enamel caused by food ingestion, the tooth may gain or lose calcium and inorganic phosphate to saliva. Therefore, this constant ion exchange is an attempt to maintain the ionic balance between these two oral environments ${ }^{12}$.

According to Ten Cate and Imfeld ${ }^{13}$ (1996), erosion is an increasingly common condition that affects children, adolescents, and adults. In a previous study ${ }^{14}$, erosion was present in $30.4 \%$ of 11 year old and $44.2 \%$ of 15 year-old adolescents. Earlier researches ${ }^{15,16}$ prove the relationship between acidic beverages consumption and the presence of enamel erosive lesions in human and bovine teeth. After World War II the consumption of artificial soft drinks significantly increased. According to the Brazilian Institute of Geography and Statistics (2004), in Brazil, soft drinks consumption increased by $490 \%$ from 1995 to $2003^{17}$.

For these reasons, the question must be asked as to whether we are able to perform a satisfactory adhesion between eroded enamel surface and fixed orthodontic appliances. Thus, the aim of this in vitro work was to evaluate the shear bond strength (SBS) of stainless steel brackets applying two conventional adhesive systems to eroded enamel, and to evaluate the adhesive remnant index (ARI) on the enamel surface.

\section{Methods}

Sixty bovine incisors, without cracks, were obtained at a slaughterhouse, and stored for a maximum of 1 week in a $0.5 \%$ Chloramine $\mathrm{T}$ solution at $4{ }^{\circ} \mathrm{C}$. After extraction, and removal of the periodontal tissues, teeth were frozen for 1 month in distilled water at $-5{ }^{\circ} \mathrm{C}$, following ISO TS $11405^{18}$.

\section{Preparation and randomization of specimens}

Subsequently, the pulp and root portions were removed with $\mathrm{Al}_{2} \mathrm{O}_{3}$ discs, and the crowns were embedded in PVC cylinders of $25 \mathrm{~mm}$ x $20 \mathrm{~mm}$ with self-curing acrylic resin. A metallic positioner, made of orthodontic stainless steel wire 0.019" x 0.025 ", and cyanoacrylate-based adhesive Super Bonder ${ }^{\mathrm{TM}}$ (Loctite, Diadema, São Paulo, Brazil) were used to set the most prominent and central portion of the buccal surface parallel to the cylinder base (Figure 1A).

To obtain a smooth, flat, and parallel enamel surface to cylinder base, the buccal portion of the teeth was worn on a polishing machine Arotec (APL4, Cotia, São Paulo, Brazil) using 400 and 600 grit sandpaper discs with water, for $10 \mathrm{~s}$. The specimens were cleaned with rubber cups at low speed and a mixture of pumice and water for $10 \mathrm{~s}$, and rinsed with air-water spray for $10 \mathrm{~s}$. Then, the teeth were numbered and divided after randomization with the Research Randomized Form program (version 4.0), in two groups: healthy group $(\mathrm{n}=30)$ and erosion group $(\mathrm{n}=30)$.

\section{Immersion protocol}

An immersion bath with Classic Coke ${ }^{\mathrm{TM}}$ (CVI Group, Santa Maria, Rio Grande do Sul, Brazil) was carried out for the erosion group with the enamel buccal surfaces upwards at the bottom of a sealed container at $37^{\circ} \mathrm{C}$. This protocol of immersion period followed the study of Von Fraunhofer and Rogers $^{19}$ (2004) for enamel demineralization by beverages solution. The Classic Coke ${ }^{\mathrm{TM}}$ was replaced every day for two weeks, totaling $336 \mathrm{~h}$ (Figure 1B). This immersion period was comparable to nearly 13 years of beverage consumption, equivalent to 710.3 $\mathrm{ml}$ daily. The healthy group (without the erosion protocol) remained in distilled water for the same time period of the erosion group, at $37^{\circ} \mathrm{C}$.

\section{Bonding of brackets}

After, the specimens were again cleaned and rinsed (Figure 1C), and randomly divided into four groups: two healthy enamel groups, and two eroded enamel groups. Furthermore, the specimens were dried with oil free air spray for $10 \mathrm{~s}$, had their surface conditioned with $37 \%$ phosphoric acid for 15 $\mathrm{s}$, cleaned with air-water spray for $20 \mathrm{~s}$, and dried again with air spray for $15 \mathrm{~s}$. Then the bonding groups were divided as follows: Group 1, without erosion and Transbond XT (3M Unitek, Monrovia, Calif, USA) adhesive system; Group 2, with erosion and Transbond XT adhesive system; Group 3, without erosion and Orthoprimer/Orthobond (Dental Morelli, Sorocaba, São Paulo, Brazil) adhesive system; and Group 4, with erosion and Orthoprimer/ Orthobond adhesive system.

Adhesive primer was applied on enamel with individual micro-brushes (KG Sorensen, Cotia, São Paulo, Brazil) per teeth, for $3 \mathrm{~s}$. Orthodontic brackets for upper central incisors with mechanic retention and $13.46 \mathrm{~mm}^{2}$ of surface area were used. The composite adhesive was applied on the bracket base and compressed onto the dental surface with a Gilmore needle, with $370 \mathrm{~g}$ for $5 \mathrm{~s}$. Adhesive excess was removed with an explorer and all samples were light-cured for $40 \mathrm{~s}$ (10 s each face) with LED Emitter B unit (Schuster, Santa Maria, Rio Grande do Sul, Brazil) with $640 \mathrm{~mW} / \mathrm{cm}^{3}$ light-intensity.

\section{Shear bond strength test}

The specimens were stored in distilled water at $37{ }^{\circ} \mathrm{C}$ for $24 \mathrm{~h}$ until the shear bond strength test, with a universal machine for mechanical testing DL-1000 (Emic, São José dos Pinhais, São Paulo, 
Brazil) with cell charge of $100 \mathrm{Kgf}$ at a crosshead speed of $1 \mathrm{~mm}$ per minute. All bracket slots were positioned horizontal to the machine and a knife-edge rod was used to deliver shear force to the ligature groove between bracket base and wings (Figure 1D). The scores were recorded on TESC software in Newtons $(\mathrm{N})$, and changed in stress $(\mathrm{MPa})$ with the load/area ratio.

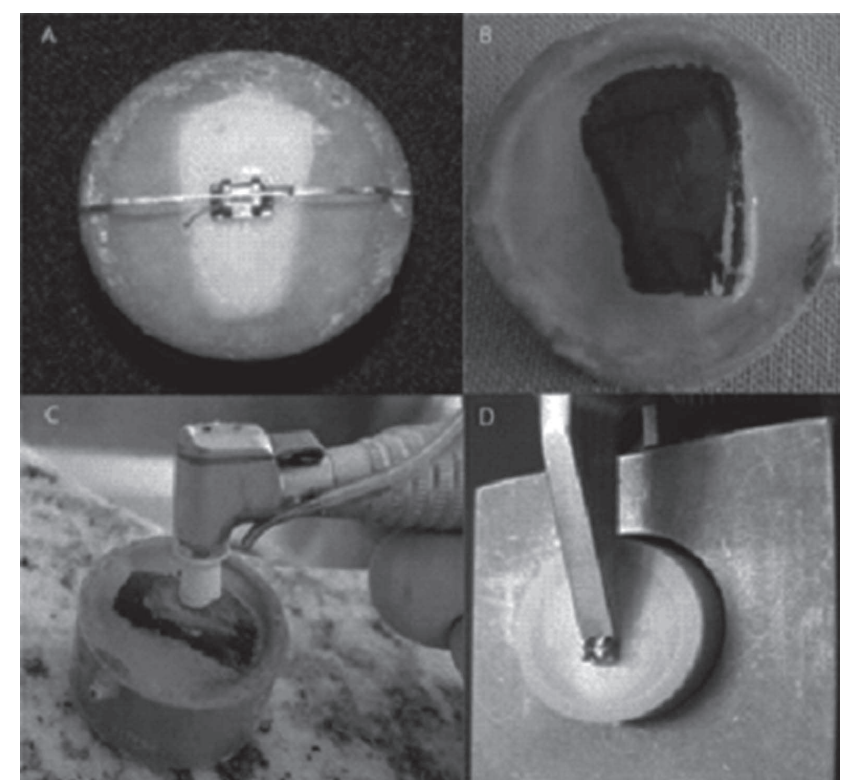

Figure 1 - A, Crown embedded in self-curing acrylic resin; B, Specimen after 14 days immersed in Classic Coke ${ }^{\circledR} ; C$, Cleaning procedures with water and pumice; D, SBS test

\section{Determination of the adhesive remnant index}

After debracketing, the enamel surfaces, bracket bases were analyzed with a stereomicroscope SR (Zeiss, Oberkochen, Baden Württenberg, Germany) with $13 x$ magnification. Then, the ARI scores (0 to 3) by Årtun and Bergland20 (1984) were assessed: 0 , no adhesive on enamel; $1,<50 \%$ adhesive on enamel; $2,>50 \%$ adhesive on enamel; and 3 , all adhesive on enamel.

\section{Statistical analysis}

Data normality was checked by Shapiro-Wilk test. The difference in the SBS among groups was analyzed by One Way ANOVA, followed by Tukey post-hoc test. To verify differences in the ARI scores distribution among groups, the nonparametric Kruskal-Wallis test was used. A significance level of 5\% was used for all tests. The Microsoft Excel (2007) and Bioestat for Windows (v. 5.0) programs were used to perform tabulation and data analysis.

\section{Results}

Significant differences of the SBS were observed when comparing the groups bonded with Transbond XT system to the groups bonded with Orthoprimer/Orthobond system (Table 1). No significant differences were found in the shear bond strength between healthy enamel groups and eroded enamel groups.

Table 1 - Mean values of SBS (MPa) and Tukey's test

\begin{tabular}{c|c|c}
\hline Group & Mean $( \pm$ SD) & Tukey* \\
\hline 1 & $19.04( \pm 3.24)$ & A \\
2 & $18.60( \pm 4.55)$ & A \\
3 & $12.76( \pm 2.78)$ & B \\
4 & $13.01( \pm 3.22)$ & B \\
\hline
\end{tabular}

Different values followed by the same letter are not statistically different ( $p$ $<0.05$ )

The ARI score 2 prevailed in the four tested groups, with over $50 \%$ of the resinous material remained on enamel surface (Figure 2). No statistically significant difference was found in the adhesive remnant index values among the groups ( $p=$ $0.3658)$.

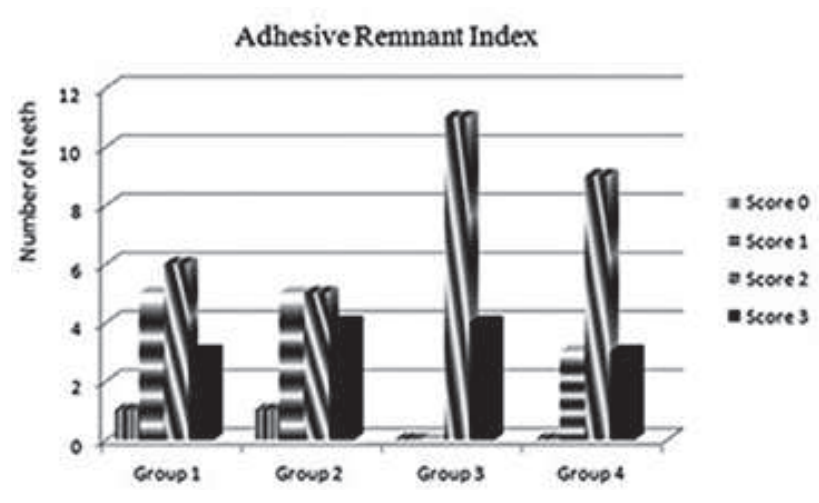

Figure 2 - ARI values distribution

\section{Discussion}

Given the inherent limitations of the in vitro experimental research, no significant differences in the shear bond strength of the orthodontic brackets were found between healthy and eroded teeth. Groups 1 and 2, using Transbond XT adhesive system obtained average SBS of, respectively, 19.04 $\mathrm{MPa}$ and $18.6 \mathrm{MPa}$, similar to previous studies ${ }^{9,21,22}$ and higher than other researches ${ }^{6,23}$. Groups 3 and 4, using Orthoprimer/Orthobond adhesive system obtained, respectively, $12.76 \mathrm{MPa}$ and $13.01 \mathrm{MPa}$. This average was also higher than previous researches $^{3}$. These great extent are explained by variations of $3.5 \mathrm{MPa}$ to $27.8 \mathrm{MPa}$ found ${ }^{5}$, and due to different methodology used in the SBS test studies, 
such as: the position of the knife-edge rod in the bracket $^{24}$, storage time after bonding ${ }^{25,26}$, bracket base area ${ }^{2}$, adhesive polymerization time, and the crosshead speed of the test ${ }^{5}$.

Significant differences were found in this study between SBS of the adhesive systems of healthy groups 1 and 3, as previously reported by Pithon et al. $^{3}$ (2008), and between eroded groups 2 and 4. However, in spite of these statistical differences found, both adhesive systems obtained SBS compatible to clinical use, higher than the average strength -6 $\mathrm{MPa}$ to $8 \mathrm{MPa}$, recommended by literature ${ }^{2,3}$.

The prevalence of the ARI score 2, over $50 \%$ adhesive on enamel, was found in this study, mainly for groups 3 and 4, with lower SBS values, nevertheless no statistical differences were found between the tested groups, in accordance with other studies ${ }^{21,24,27}$. The conventional adhesives tend to leave a larger number of adhesive remnant on the tooth $^{22,28}$, which agrees with the findings of this research. Only two teeth remained with no adhesive on enamel surface after debonding. However, we noticed a decrease of the adhesive remnant on enamel in Groups 1 and 2, with higher SBS. Vilchis et al. $^{9}$ (2009) reported that fractures may occur on enamel with SBS values above $14 \mathrm{MPa}$, which was not observed in this study.

The Classic Coke ${ }^{\mathrm{TM}}$ beverage, in spite of being quite consumed, presents acidic $\mathrm{pH}$ of about 2.5, and is considered to cause enamel dissolution ${ }^{15,16,29}$. Carbonated soft drinks are more erosive than non-carbonated by the additional presence of carbonic $\operatorname{acid}^{30}$. Nevertheless, the erosion potential of beverages on enamel surface can change according to each country's means of production ${ }^{29}$. In addition, during orthodontic treatment, the adhesive excess around brackets may cause dental plaque accumulation, increasing decalcification risks.

To create the erosion protocol, used by this study, Von Fraunhofer and Rogers ${ }^{19}$ (2004) estimated a daily intake of soft drinks totaling $90.000 \mathrm{~s}$ per year of enamel surface contact, a reasonable time period to evaluate the erosion potential on enamel of children and young adults. This Coca-Cola consumption had generated enamel dissolution of almost 3.0 $\mathrm{mg} / \mathrm{cm}^{2}$, near 55-65 times more than water. This protocol was also used by Owens and Kitchens ${ }^{15}$, (2007) however, there is little information about its previous use in relation to orthodontic bonding and the aim to test the SBS between eroded enamel and adhesive systems. A limitation of our study arises from causing the in vitro enamel erosion, since important enamel protections such as saliva, and lips and tongue touch are omitted. Since the microscopic analysis of the eroded enamel surface were not the aim of this work, further studies are required to understand the role of this erosion protocol on micro morphologic changes of the eroded enamel.
The complexity of dental erosion and the appearance of bonding materials raise new questions about adhesive system performances in relation to the SBS of orthodontic brackets, in order to test other erosive agents and protocols.

\section{Conclusion}

- The eroded enamel did not change the SBS of metallic brackets bonded with two different adhesive systems.

- The Transbond XT adhesive system presented higher SBS when compared to Orthoprimer/Orthobond adhesive system.

- ARI values had no statistically significant changes among the evaluated groups.

\section{Resumo}

Objetivo: avaliar a resistência de união ao cisalhamento de bráquetes metálicos colados com dois sistemas adesivos em dentes submetidos à erosão ácida. Métodos: foram utilizados 60 incisivos inferiores bovinos, divididos em quatro grupos $(n=15)$. As colagens foram realizadas com bráquetes metálicos e condicionamento com ácido fosfórico $37 \%$, divididas da seguinte maneira: Grupo 1, em dentes hígidos com sistema adesivo Transbond XT (3M Unitek, Monrovia, EUA); Grupo 2, em dentes submetidos à erosão com sistema adesivo Transbond XT; Grupo 3, em dentes hígidos com sistema adesivo Orthoprimer/Orthobond (Dental Morelli Ltda, Sorocaba, Brasil); e Grupo 4, em dentes submetidos à erosão com sistema adesivo Orthoprimer/Orthobond. A erosão dentária foi causada por Coca-Cola Clássica ${ }^{\circledR}$ durante 14 dias. O ensaio de cisalhamento ocorreu 24 $h$ após a colagem e foi realizado à velocidade de $1 \mathrm{~mm} /$ min em uma máquina universal de ensaios mecânicos. Resultados: as médias de resistência de união encontradas foram de: Grupo 1, 19,04(3,24) MPa; Grupo 2, 18,6(4,25) MPa; Grupo 3, 12,76(2,78) MPa; e Grupo 4, 13,01(3,22) MPa. Não foram encontradas diferenças estatisticamente significativas entre os grupos 1 e 2 e entre os grupos 3 e 4 . Houve diferença estatisticamente significativa entre os grupos 1 e 3 e entre os grupos 2 e 4. Quanto ao índice de remanescente adesivo (IRA) não foi observada diferença significativa entre os quatro grupos avaliados. Conclusões: a erosão ácida não alterou a resistência de união ao cisalhamento de bráquetes metálicos colados com os dois sistemas adesivos testados. O sistema adesivo Transbond XT apresentou maior resistência de união que o sistema adesivo Orthoprimer/Orthobond.

Palavras-chave: Erosão dentária. Bráquetes ortodônticos. Adesivos ortodônticos. 


\section{References}

1. Mitchell DL. Bandless orthodontic bracket. J Am Dent Assoc 1967; 74:103-10.

2. Cozza P, Martucci L, Toffol L, Penco SI. Shear bond strength of metal brackets on enamel. Angle Orthod 2006; 76(5):8516.

3. Pithon MM, Santos RL, Oliveira MV, Sant'anna EF, Ruellas ACO. Avaliação da resistência ao cisalhamento do compósito Orthobond em diferentes condições. RGO 2008; 56(4):405-10.

4. Osorio R, Toledano M, Garcia-Godoy F. Bracket bonding with 15- or 60-second etching and adhesive remaning on enamel after debonding. Angle Orthod 1999; 69(1):45-8.

5. Finnema KJ, Özcan M, Post WJ, Ren Y, Dijkstra PU. In-vitro orthodontic bond strength testing: a systematic review and meta-analysis. Am J Orthod Dentofacial Orthop 2010; 137(5):615-22.

6. Cacciafesta V, Sfondrini MF, Scribante A, Angelis M, Klersy C. Effect of water and saliva contamination on shear bond strength of brackets bonded with conventional, hydrophilic, and self-etching primers. Am J Orthod Dentofacial Orthop 2003; 123(6):633-40.

7. Lowder PD, Foley T, Banting DW. Bond strength of 4 orthodontic adhesives used with a caries-protective resin sealant. Am J Orthod Dentofacial Orthop 2008; 134(2):291-5.

8. Minick GT, Oesterle LJ, Newman SM, Shellhart WC. Bracket bond strength of new adhesive system. Am J Orthod Dentofacial Orthop 2009; 135(6):771-6.

9. Vilchis RJ, Yamamoto S, Kitai N, Yamamoto K. Shear bond strength of orthodontic brackets bonded with different self-etching adhesives. Am J Orthod Dentofacial Orthop 2009; 136(3):425-30.

10. Sharma-Sayal S, Rossouw PE, Kulkarni GV, Titley KC. The influence of orthodontic base design on shear bond strength. Am J Orthod Dentofacial Orthop 2003; 124(1):74-82.

11. El Aidi H, Bronckhorst E, Truin G. A longitudinal study of tooth erosion in adolescents. J Dent Res 2008; 87(8):731-5.

12. Cardoso AC. Oclusão: para você e para mim. São Paulo: Santos; 2007.

13. Ten Cate JM, Imfeld T. Dental erosion. Eur J Oral Sci 1996; 104:241-4.

14. El Aidi H, Bronckhorst EM, Huysmans MC, Truin G. Dynamics of tooth erosion in adolescents: a 3-year longitudinal study. J Dent 2010; 38(2):131-7.

15. Owens BM, Kitchens M. The erosive potential of soft drinks on enamel surface substrate: an in vitro scanning electron microscopy investigation. J Contemp Dent Pract 2007; 8(7):11-20.

16. Ehlen LA, Marshall TA, Qian F, Wefel JS, Warren JJ. Acidic beverages increase the risk of in vitro tooth erosion. Nutr Res 2008; 28:299-303.

17. Kato MT, Italiani FM, Araújo JJ, Garcia MD, Sales-Peres SHC, Buzalaf MAR. Preventive effect of an iron varnish on bovine enamel erosion in vitro. J Dent 2009; 37:233-6.

18. ISO TS 11405. Dental materials - testing of adhesion to tooth structure. 2. ed. Geneva: International Organization for Standardization; 2003.
19. Von Fraunhofer JA, Rogers MM. Dissolution of dental enamel in soft drinks. Gen Dent 2004; 29(4):308-12.

20. Årtun J, Bergland S. Clinical trials with crystal growth conditioning as an alternative to acid-etch enamel pretreatment. Am J Orthod 1984; 85:333-40.

21. Zeppieri IL, Chung C, Mante FK. Effect of saliva on shear bond strength of an orthodontic adhesive used with moisture insensitive and self-etching primers. Am J Orthod Dentofacial Orthop 2003; 124(4):414-9.

22. Holzmeier M, Schaubmayr M, Dasch W, Hirschfelder U. A new generation of self-etching adhesives: comparison with traditional acid etch technique. J Orofac Orthop 2008; 69(2):78-93.

23. Vasques WO, Ciruffo PSD, Tubel CAM, Miyamura CAM, Vedovello Filho M. Resistência ao cisalhamento de diferentes bráquetes metálicos. RGO 2005; 53(3):186-90.

24. Klocke A, Kahl-Nieke B. Influence of force location in orthodontic shear bond strength testing. Dent Mater 2005; 21:391-6.

25. Gittner R, Müller-Hartwich R, Jost-Brinkmann P. Influence of various storage media on shear bond strength and enamel fracture when debonding ceramic brackets: an in vitro study. Semin Orthod 2010; 16(1):49-54.

26. Yamamoto A, Yoshida T, Tsubota K, Takamizawa T, Kurokawa H, Miyazaki M. Orthodontic bracket bonding: enamel bond strength versus time. Am J Orthod Dentofacial Orthop 2006; 130(4):435.e1-435.e6.

27. Faltermeier A, Behr M, Müssig D. A comparative evaluation of bracket bonding with 1-, 2-, and 3-component adhesive systems. Am J Orthod Dentofacial Orthop 2007; 132(2):144. e1-144.e5.

28. Bishara SE, Gordan VV, Von Wald L, Olson ME. Effect of an acidic primer on shear bond strength of orthodontic brackets. Am J Orthod Dentofacial Orthop 1998; 114(3); 243-7.

29. Murrel S, Marshall TA, Moynihan PJ, Qian F, Wefel JS. Comparison of in vitro erosion potentials between beverages available in the United Kingdom and the United States. J Dent 2009; 38(4):284-9.

30. Oncag G, Tuncer AV, Tosun YS. Acidic drinks effects on the shear bond strength of orthodontic brackets and a scanning electron microscopy evaluation of the enamel. Angle Orthod 2005; 75(2):247-53.

\section{Corresponding author:}

Felipe Weidenbach Degrazia

Rua Floriano Peixoto, 1124, sala 301

97010-370 - Santa Maria-RS, Brazil

Phone: +55 55 3221-7214 / +55 55 99970047

E-mail: fdegrazia@hotmail.com

Recebido: 11/04/2013. Aceito: 25/06/2013. 